\title{
ANALISIS HASIL KINERJA PDAM DALAM UPAYA MENINGKATKAN PAD PEMERINTAH PROVINSI DAN KABUPATEN/KOTA DI KALIMANTAN SELATAN
}

\author{
Muhammad Saleh, Nasrudin, Ruddy Syafrudin \\ Fakultas Ekonomi dan Bisnis Universitas Lambung Mangkurat
}

\begin{abstract}
The purpose of this research is to find the bealth level of PDAM in South Kalimantan, their potential in contributing to the province's $P A D$, and factors that influences their performance. The data is analyzed using descriptivequantitative method. The research shows that there are 12 PDAM in South Kalimantan, 3 (three) of them are in a bealthy condition, but only two of them that can contribute to province's $P A D$. All PDAM bave great potential in contributing to $P A D$ if there are improvement in capital, management of employees, and supervision. As for factors that influences their performance is the internal factors consisting of low capital, low quality of employees, and weak supervision, then external factors caused by the state of local economic, so many people don't pay their water bill that influence the all other financial performance.
\end{abstract}

Abstrak: Tujuan Penelitian ini adalah untuk mengetahui tingkat kesehatan PDAM di Kalimantan Selatan, Potensi PDAM dalam menyumbang PAD Provinsi dan Kabupaten di Kalimantan Selatan, dan faktorfaktor yang mempengaruhi kinerja PDAM di Kalimantan Selatan. Data dianalisis menggunakan metode deskriftif kuantitatif. Hasilnya penelitian menunjukkan bahwa jumlah PDAM di Kalimantan Selatan sebanyak 12 buah dimana sebanyak 3 (tiga) diantaranya dalam kondisi sehat tetapi hanya 2 (dua) PDAM yang dapat menyumbang PAD. Kedua belas PDAM tersebut punya potensi besar dalam menyumbang PAD jika dilakukan perbaikan modal, manajemen (karyawan), dan pengawasan. Adapun faktor- faktor yang mempengaruhi kinerja BPR adalah faktor internal yang terdiri dari modal setor yang masih rendah, kualitas karyawan masih rendah dan pengawasan yang masih kurang, kemudian faktor eksternal terdiri dari keadaan ekonomi lokal sehingga banyak masyarakat yang tidak membayar rekening airnya dan mempengaruhi kinerja keuangan lainnya.

Kata Kunci: Tingkat Kesehatan PD AM, Kinerja PD AM dan PAD

\section{Latar Belakang}

Perusahaan Daerah diatur berdasarkan UU No. 5 Tahun 1962. Perusahaan Daerah adalah perusahaan yang saham-sahamnya dimiliki oleh Pemerintah Daerah, serta pengaturannya diatur dalam Peraturan Daerah yang bersangkutan. Yang dimaksud Perusahaan Daerah adalah semua perusahaan yang didirikan berdasarkan UndangUndang Perusahan Daerah, yang didirikan dengan Peraturan Daerah dan merupakan badan hukum serta kedudukannya diperoleh dengan berlakunya Peraturan Daerah tersebut. Peraturan Daerah ini mulai berlaku setelah mendapat pengesahan instansi atasan. Perusahan Daerah adalah suatu kesatuan produksi yang bersifat memberi jasa, menyelenggarakan kemanfaatan umum dan memupuk pendapatan.

Dalam Undang-Undang Nomor 23 Tahun 2014 tentang Pemerintah Daerah dan dirubah dengan Undang- Undang Nomor 9 tahun 2015 menyebutkan bahwa Pemerintah Daerah dapat memiliki BUMD yang pembentukan, penggabungan, pelepasan kepemilikan, dan/atau pembubarannya ditetapkan dengan Peraturan Daerah yang berpedoman pada peraturan perundang-undangan. Tujuan Perusahaan Daerah adalah turut serta melaksanakan pembangunan daerah khususnya dan pembangunan ekonomi nasional umumnya dalam rangka demokrasi ekonomi untuk memenuhi kebutuhan rakyat dengan mengutamakan industrialisasi dan ketentraman serta kegairahan kerja dalam perusahaan, serta menuju masyarakat adil dan makmur.

Perusahaan Daerah Air Minum (PDAM) berbeda dengan perusahaan swasta murni yang selalu berorientasi pada keuntungan (profit oriented). Salah satu tujuan PDAM adalah turut serta dalam melaksanakan pembangunan daerah khususnya, dan pembangunan ekonomi nasional pada umumnya, dengan cara menyediakan air minum yang bersih, sehat, dan memenuhi persyaratan kesehatan bagi masyarakat di suatu daerah, yang sekaligus merupakan wujud pelayanan yang diberikan oleh pemerintah terhadap masyarakat.

Apabila merujuk pada Keputusan Menteri Dalam Negeri No: 690-069 tahun 1992, tentang Pola Petunjuk Teknis Pengelolaan PDAM, di sana ditegaskan bahwa PDAM mempunyai tugas pokok pelayanan umum kepada masyarakat, di mana dalam menjalankan fungsinya PDAM diharapkan mampu membiayai dirinya sendiri (self financing) 
dan harus berusaha mengembangkan tingkat pelayanannya, di samping itu PDAM juga diharapkan mampu memberikan sumbangan pembangunan kepada Pemda. Selanjutnya dalam keputusan Menteri Dalam Negeri Nomor 47 Tahun 1999, tentang Pedoman Penilaian Kinerja PDAM dinyatakan bahwa tujuan pendirian PDAM adalah untuk memenuhi pelayanan dan kebutuhan akan air bersih bagi masyarakat serta sebagai salah satu sumber Pendapatan Asli Daerah (PAD).

Untuk mencapai tujuan di atas, maka penyelenggaraan, pengelolaan, dan pembinaan terhadap PDAM harus berdasarkan kepada prinsip-prinsip dan azas ekonomi perusahaan yang sehat. Dari ketentuan yang mengatur tentang keberadaan PDAM sangat jelas bahwa dalam menjalankan fungsinya sebagai penyedia air bersih dan dalam upaya peningkatan pelayanan publik tidak terlepas dari dimensi ekonomi yaitu memperoleh keuntungan.

Adanya kepentingan pelayanan publik menyebabkan PDAM tidak akan mampu menjalankan fungsinya secara optimal, sehingga keadaan ini akan mempengaruhi kinerja perusahaan secara keseluruhan. Untuk mewujudkan kedua tujuan dimaksud pengelolaan PDAM masih dihadapkan pada inefisiensi bahkan cenderung mengedepankan fungsi pelayanan publik (public service oriented), sehingga berdampak keberadaannya membebani keuangan daerah. Berkaitan dengan tujuan untuk memperoleh keuntungan (profit oriented) pengelolaan operasi PDAM diharapkan mampu membiayai biaya operasionalnya sendiri (self financing) dan diharapkan dapat menopang pembiayaan dalam meningkatkan pelayanan kepada masyarakat dalam jangka pendek serta mampu memberikan kontribusi pada penerimaan daerah (PAD) untuk jangka panjangnya.

Untuk itu dalam perspektif ke depan manajemen pengelolaan Badan Usaha Milik Daerah termasuk di dalamnya adalah PDAM diharapkan mampu mengadopsi prinsip-prinsip manajemen professional. Dengan menerapkan prinsip dimaksud, maka dalam menyediakan pelayanan kepada masyarakat harus tetap mempertimbangkan cost and benefit sehingga biaya pungutan atas pelayanan yang diberikan (cost of service) dapat benar-benar membantu pemerintah daerah meningkatkan kualitas pelayanan di bidang penyediaan air bersih pada khususnya dan pelayanan pemerintah pada umumnya di masa yang akan datang.

Mengingat keberadaan PDAM dibiayai oleh Pemerintah Daerah yang bersumber dari uang masyarakat (public fund) maka dalam pengelolaanya harus memperhatikan aspek transparansi dan akuntabilitas, baik dalam aspek pengelolaan keuangan, aspek operasional dan aspek administrasinya, karena ketiga aspek dimaksud sangat menetukan kinerja pengelolaan Perusahaan Daerah Air Minum (PDAM). Dengan baiknya kinerja PDAM diharapkan dapat menyumbang PAD bagi daerah yang bersangkutan.

Namun demikian PDAM yang ada di Provinsi Kalimantan Selatan sebagai salah satu komponen PAD belum memperlihatkan pengaruh yang berarti terhadap Peningkatan Pendapatan Asli Daerah. Bahkan ada indikasi bahwa perusahaan daerah selama ini hanya membebani pemerintah daerah dengan berbagai subsidi terselubung dan biaya semu, sehingga perusahaan daerah tidak mempunyai kemandirian dalam menjalankan usahanya.

Kinerja keuangan PDAM di Kalimantan Selatan yang berjumlah 12 buah belum menunjukkan perbaikan yang berarti. Jika dilihat dari lporan keuangannya hanya ada 3(tiga) buah PDAM yang mendapatkan keuntungan yaitu PDAM Intan Banjar, PDAM Hulu Sungai Selatan dan PDAM Bandar Masih, sisanya sebanyak 9 (Sembilan) buah PDAM masih mengalami kerugian. Keadaan ini sangat menarik untuk diteliti lebih mendalam apa saja yang menyebabkan kinerja PDAM di Kalimantan Selatan belum memuaskan dan terlihat sebagian besar masih membebani APBD. Walaupun harus maklum PDAM juga punya misi sosial bagi masyarakat setempat.

\section{Landasan Teori}

\section{A. Pengelolaan BUMN dan BUMD}

Menurut Akadun (2007) bahwa dalam perjalanan pengelolaan BUMN di Indonesia ternyata kinenerja sebagian besar BUMN terpuruk, kurang sehat (atau bahkan tidak sehat); terus menerus merugi, inefisiensi, menyedot dana APBN serta mengalami patologi birokrasi dan maladministration. Antara lain penyebabnya : (1) Administrasi Perusahaan Negara berada di antara bayangbayang administrasi negara dengan administrasi bisnis. Implikasinya mekanisme pasar tidak berjalan dengan secara optimal. Misalnya dalam hal penentuan harga (tarif dasar). (2)Tujuan BUMN mengejar keuntungan (profit). BUMN dituntut untuk menjadi perintis suatu usaha meskipun harus merugi; dituntut untuk menghasilkan barang dan jasa yang memberikan kemanfatan umum, disisi dituntut mendapatkan keuntungan sehingga memberikan kontribusi bagi penerimaan 
negara. (3) Campur aduknya kepentingan sosial-politik dengan ekonomi dalam pengekolaan BUMN. Partai Politik ikut dalam manajemen BUMN dengan kepentingan politik. (4) Pembinaan dan pengawasaan tehadap kinerja manajemen BUMN dilakukan oleh berbagai pihak, yakni Kementerian Negara BUMN, departemen teknis dan departemen keuangan sehingga sering terjadi benturan-benturan kepentingan.(5). Masih belum tercapainya persepsi dan konsepsi yang sama di antara stakeholders (pemangku kepentingan atau pengguna) tentang "cabangcabang produksi yang penting bagi negara dan yang menguasai hajat hidup orang banyak" sehingga "usaha-usaha apa saja" yang dapat dikelola oleh BUMN masih terus menjadi bahan perdebatan.

Perusahaan Daerah diatur berdasarkan UU No. 5 Tahun 1962. Perusahaan Daerah adalah perusahaan yang saham-sahamnya dimiliki oleh Pemerintah Daerah, serta pengaturannya diatur dalam peraturan daerah yang bersangkutan. Yang dimaksud Perusahaan adalah semua perusahaan yang didirikan berdasarkan Undang-Undang Perusahan Daerah, yang didirikan dengan Peraturan Daerah dan merupakan badan hukum serta kedudukannya diperoleh dengan berlakunya peraturan daerah tersebut. Peraturan Daerah ini mulai berlaku setelah mendapat pengesahan instansi atasan. Perusahan Daerah adalah suatu kesatuan produksi yang bersifat memberi jasa, menyelenggarakan kemanfaatan umum dan memupuk pendapatan.

Dalam Undang-Undang Nomor 23 tahun 2014 yang disempurnakan dengan UndangUndang Nomor 9 tahun 2015 tentang Pemerintah Daerah menyebutkan bahwa Pemerintah Daerah dapat memiliki BUMD yang pembentukan, penggabungan, pelepasan kepemilikan, dan/atau pembubarannya ditetapkan dengan Peraturan Daerah yang berpedoman pada peraturan perundangundangan. Tujuan Perusahaan Daerah adalah turut serta melaksanakan pembangunan daerah khususnya dan pembangunan ekonomi nasional umumnya dalam rangka demokrasi ekonomi untuk memenuhi kebutuhan rakyat dengan mengutamakan industrialisasi dan ketentraman serta kegairahan kerja dalam perusahaan, serta menuju masyarakat adil dan makmur.

Perusahaan Daerah Air Minum (PDAM) berbeda dengan perusahaan swasta murni yang selalu berorientasi pada keuntungan (profit oriented). Salah satu tujuan PDAM adalah turut serta dalam melaksanakan pembangunan daerah khususnya, dan pembangunan ekonomi nasional pada umumnya, dengan cara menyediakan air minum yang bersih, sehat, dan memenuhi persyaratan kesehatan bagi masyarakat di suatu daerah, yang sekaligus merupakan wujud pelayanan yang diberikan oleh pemerintah terhadap masyarakat.

Apabila merujuk pada Keputusan Menteri Dalam Negeri No: 690-069 tahun 1992, tentang Pola Petunjuk Teknis Pengelolaan PDAM, di sana ditegaskan bahwa PDAM mempunyai tugas pokok pelayanan umum kepada masyarakat, di mana dalam menjalankan fungsinya PDAM diharapkan mampu membiayai dirinya sendiri (self financing) dan harus berusaha mengembangkan tingkat pelayanannya, di samping itu PDAM juga diharapkan mampu memberikan sumbangan pembangunan kepada Pemda. Selanjutnya dalam keputusan Menteri Dalam Negeri Nomor 47 Tahun 1999, tentang Pedoman Penilaian Kinerja PDAM dinyatakan bahwa tujuan pendirian PDAM adalah untuk memenuhi pelayanan dan kebutuhan akan air bersih bagi masyarakat serta sebagai salah satu sumber PAD. Untuk mencapai tujuan di atas, maka penyelenggaraan, pengelolaan, dan pembinaan terhadap PDAM harus berdasarkan kepada prinsip-prinsip dan azas ekonomi perusahaan yang sehat. Dari ketentuan yang mengatur tentang keberadaan PDAM sangat jelas bahwa dalam menjalankan fungsinya sebagai penyedia air bersih dan dalam upaya peningkatan pelayanan publik tidak terlepas dari dimensi ekonomi yaitu memperoleh keuntungan yang memadai.

Mengingat keberadaan PDAM dibiayai oleh pemerintah daerah yang bersumber dari uang masyarakat (public fund) maka dalam pengelolaanya harus memperhatikan aspek transparansi dan akuntabilitas, baik dalam aspek pengelolaan keuangan, aspek operasional dan aspek administrasinya, karena ketiga aspek dimaksud sangat menetukan kinerja pengelolaan perusahaan termasuk di dalamnya adalah Perusahaan Daerah Air Minum (PDAM).

\section{B. Pihak-Pihak yang Berkepentingan}

Banyak pihak yang mempunyai kepentingan untuk mengetahui lebih mendalam tentang kondisi PDAM melalui laporan hasil audit kinerja, karena masing-masing pihak mempunyai kepentingan yang berbeda, maka sudah tentu mereka akan memberikan tekanan 
tekanan analisis pendekatan-pendekatan maupun cara-cara analisis yang berbeda. (1). Kepentingan Pemegang Saham/Pemilik, antara lain Pemerintah Pusat/ Pemerintah Daerah, dan sekelompok individu pengusaha. (2). Kepentingan pajak.. (3). Kepentingan Pemerintah. (4). Karyawan (5). Manajemen PDAM.

\section{Ukuran-Ukuran Kinerja Keuangan}

Kinerja keuangan adalah ukuran tingkat keberhasilan perusahaan yang diukur dengan tiga kriteria, yaitu: a) tingkat keberhasilan memperoleh keuntungan (profitabilitas usaha), b) kemampuan menyusun struktur pendanaan secara efisien (solvabilitas perusahaan), dan c) kemampuan perusahaan melunasi utang yang telah jatuh tempo (likuiditas keuangan) Sutojo (2000).

Dalam analisis internal, banyak perusahaan yang menerapkan sistem rasio dan standar yang memisahkannya ke dalam komponen serangkaian keputusan yang mempengaruhi kinerja operasional, keseluruhan returns, dan harapan pemegang saham. Untuk memperlihatkan hubungannya digunakan dua parameter kunci yang dipisahkan ke dalam elemennya masing-masing. Return on Assets $(\mathrm{RO} A)$ untuk menilai kinerja manajemen dan, Return on Equity (ROE) yang memberikan ukuran kunci dari sudut pandang pemilik.

D. Tingkat Kinerja PDAM Menurut Kemendagri Nomor 47 Tahun 1999

Menurut Kemendagri Nomor 47 Tahun 1999 tersebut pada Pasal 3 ayat (1) Tingkat keberhasilan PDAM adalah:

1. Baik Sekali, bila memperoleh nilai kinerja diatas 75;

2. Baik, bila memperoleh nilai kinerja diatas 60 sampai dengan 75 ;

3. Cukup, bila memperoleh nilai kinerja diatas 45 sampai dengan 60;

4. Kurang, bila memperoleh nilai kinerja diatas 30 sampai dengan 45;

5. Tidak Baik, bila memperoleh nilai kinerja kurang dari atau sama dengan 30.

Kemudian pada ayat (2) Bobot untuk masing-masing aspek adalah: (a). Aspek Keuangan 45; (b). Aspek Operasional 40; (c). Aspek Administrasi 15, kemudian pada ayat (3) berbunyi indikator setiap aspek terdiri atas:

1. Aspek Keuangan: (a). Rasio Laba terhadap Aktiva Produktif; (b). Rasio Laba terhadap Penjualan; (c). Rasio Aktiva Lancar terhadap Utang Lancar; (d). Rasio Utang Jangka Panjang terhadap Total Utang; (e). Rasio Total Aktiva terhadap Total Utang; (f). Rasio Biaya Operasi terhadap Pendapatan Operasi; (g). Rasion Laba Operasi sebelum Biaya Penyusulan terhadap Angsuran Pokok, (h). Bunga Jatuh Tempo; (i). Rasio Aktiva Produktif terhadap Penjualan Air; (j). Jangka Waktu Penagihan Piutang; dan (k). Efektivitas Penagihan.

2. Aspek Operasional : (a). Cakupan Pelayanan; (b). Kualitas Air Distribusi; (c). Kontinuitas Air; (d). Produktifitas Pemanfaatan Instalasi Produksi; (e). Tingkat Kehilangan Air; (f). Peneraan Meter Air; (g). Kecepatan Penyambungan Baru; (h). Kemampuan Penanganan Pengaduan Rata-rata per bulan; (i). Kemudahan Pelayanan; (j). Rasio Karyawan per 1000 pelanggan.

3. Aspek Administrasi: (a). Rencana Jangka Panjang (Corporate Plan); (b). Rencana Organisasi dan Uraian Tugas; (c). Prosedur Operasi Standar; (d). Gambar Nyata Laksana (As Built Drawing); (e). Pedoman Penilaian Kerja Karyawan: (f). Rencana Kerja dan Anggaran Perusahaan (RKAP); (g). Tertib Laporan Internal; (h). Tertib Laporan Eksternal; (i). Opini Auditor Independen; (j).Tindak lanjut hasil pemeriksaan tahun terakhir.

Di berikan nilai tambah berupa bonus dengan memperbandingkan hasil tahun buku saat ini dan sebelumnya. Kemudian pada ayat (5) Jumlah nilai indikator maksimum pada masing-masing aspek adalah: (a). Aspek Keuangan 60; (b). Aspek Operasional 47; (c). Aspek Administrasi 36.

\section{Metode Penelitian}

\section{A. Lokasi Penelitian}

Lokasi penelitian adalah seluruh kabupaten/ kota di Provinsi Kalimantan Selatan yang ada Perusahaan Daerah Air Minum (PDAM).

\section{B. Data yang Diperlukan}

Data yang diperlukan dalam analisis PDAM ini adalah laporan hasil audit kinerja PDAM Kabupaten/Kota Se Kalimantan Selatan khususnya tahun buku terakhir yang dilakukan oleh Badan Pengawas Keuangan Dan Pembangunan (BPKP) Perwakilan Provinsi Kalimantan Selatan. Data yang telah diaudit BPKP pada tahun terakhir tidak seragam ada yang sampai tahun 2015 tetapi ada juga yang baru sampai tahun 2014 , yang seragam hanya sampai tahun 2014 maka diambil data sampai dengan tahun 2014. Hal ini dilakukan untuk konsestensi data. 


\section{Sumber Data dan Cara Memperolehnya}

Sumber data dalam bentuk data sekunder dan data primer. Data sekunder diperoleh dari instansi-instansi pemerintah, data tersebut antara lain (1) berbagai publikasi yang diterbitkan oleh Biro Pusat Statistik atau Statistik Daerah, seperti: berbagai daerah dalam angka, (2) publikasi yang dikeluarkan oleh BPKMD, seperti daftar skala prioritas, (3) publikasi yang dikeluarkan oleh PDAM, juga informasi perbankan dan industri dari sumber lainnya. Data primer akan difokuskan untuk melakukan wawancara dengan para pimpinan PDAM dalam upaya pengembangan usaha.

D. Instrumen Pengumpulan Data

Instrumen yang digunakan dalam pengumpulan data, yaitu :

1. Form Check List, untuk mengumpulkan data dokumentasi dan data sekunder dari berbagai sumber.

2. Kuesioner, untuk mengumpulkan data primer dari kelompok sasaran selama pelaksanaan survei.

\section{E. Metode Analisis}

Untuk mencapai tujuan yang dimaksud maka analisis yang digunakan adalah analisis deskriptif kuantitatif, yaitu menganalisis dan menafsirkan data kuantitatif yang didapatkan dalam penelitian ini sesuai dengan teori.

\section{F. Ruang Lingkup Penelitian}

Faktor-faktor yang menjadi ruang lingkup penelitian ini antara lain :
1. Makro Ekonomi meliputi seluruh faktor yang mempengaruhi kondisi perekonomian Provinsi Kalimantan Selatan seperti pertumbuhan ekonomi, inflasi, kebijakan pemerintah, perubahan faktor-faktor makro ekonomi lainnya.

2. Mikro Ekonomi meliputi kondisi dan kemampuan perusahaan (PDAM), kemudian pembagian Deviden untuk Pemerintah Provinsi Kalimantan Selatan dan Pemerintah Kabupaten yang memiliki modal pada PDAM yang bersangkutan.

3. Faktor Perekonomian Wilayah yaitu kondisi perekonomian daerah.

\section{Hasil Penelitian}

Jadi dari hasil analisis diatas bahwa dapat disimpulkan hanya 3 (tiga) PDAM yang sehat pada tahun 2013 dan 2014, yaitu PDAM Intan Banjar, PDAM Bandarmasih dan PDAM Kabupaten Hulu Sungai Selatan (tabel : 1). Tetapi PDAM Kabupaten Hulu Sungai Selatan sebenarnya masih menanggung kerugian yang besar pada tahuntahun sebelumnya sehingga jika keuntungan yang didapat pada tahun 2013 dan 2014 dikurangi dengan kerugian yang terjadi pada tahun sebelumnya maka PDAM Kabupaten Hulu Sungai Selatan masih mengalami kerugian. Jika PDAM sehat maka akan dapat menghasilkan laba sehingga dapat menyumbang Pendapatan Asli Daerah (PAD), atau minimal tidak membebani APBD.

Tabel 1. Rekapitulasi Katagori Kesehatan PDAM di Kalimantan Selatan Tahun 2014

\begin{tabular}{clcc}
\hline No & \multicolumn{1}{c}{ Nama PDAM } & Kabupaten & Katagori Kesehatan \\
\hline 1. & PDAM Kabupaten Barito Kuala & Kab. Batola & Belum sehat \\
\hline 2. & PDAM Intan Banjar & Kab. Banjar \& Banjarbaru & Sehat \\
\hline 3. & PDAM Kabupaten Balangan & Kab. Balangan & Belum sehat \\
\hline 4. & PDAM Kabupaten Tanah Laut & Kab. Tala & Belum sehat \\
\hline 5. & PDAM Kabupaten Hulu Sungai Tengah & Kab. HST & Belum sehat \\
\hline 6. & PDAM Kabupaten Hulu Sungai Utara & Kab. HSU & Belum sehat \\
\hline 7. & PDAM Kabupaten Tapin & Kab. Tapin & Belum sehat \\
\hline 8. & PDAM Kabupaten Bandarmasih & Kota Banjarmasin & Sehat \\
\hline 9. & PDAM Kabupaten Hulu Sungai Selatan & Kab. HSS & Sehat \\
\hline 10. & PDAM Kabupaten Tanah Bumbu & Kab. Tanah Bumbu & Belum sehat \\
\hline 11. & PDAM Kabupaten Kotabaru & Kab. Kotabaru & Belum sehat \\
\hline 12 & PDAM Kabupaten Tabalong & Kabupaten Tabalong & Belum sehat \\
\hline
\end{tabular}

Sumber: Hasil analisis, 2016

Hasil penelitian didapatkan juga bahwa penyebab utama ruginya PDAM adalah disebabkan tarif yang masih rendah. Memang jadi delematis bagi Pemerintah Daerah untuk menaikkan tarif air. Jika dinaikan tarif maka konsumen (masyarakat) berpenghasilan rendah akan tidak mampu membayarnya, padahal ada tugas Pemerintah Daerah untuk mensejahterakan 
rakyatnya dengan mengkonsumsi air bersih. Memang berbeda Perusahaan Negara/ Daerah dengan perusahaan swasta, jika perusahaan swasta yang tujuannya mencari keuntungan maksimum, tetapi perusahaan daerah tujuannya lebih banyak diartikan untuk mencapai kesejahteraan umum (summum bonum).

\section{A. Potensi PDAM Dalam Menyumbang PAD}

Besarnya PAD yang didapat tergantung pada hasil laba yang didapat dan saham yang ditanamkan oleh masing- masing Pemerintah Provinsi dan Pemerintah Kabupaten. Secara keseluruhan Pemerintah Provinsi Kalimantan Selatan punya modal pada PDAM rata- rata sebesar 10,47\% dan Pemerintah Kabupaten/ Kota besar modalnya sangat beragam dan rata $80,17 \%$ kemudian modal pemerintah yang belum ditetapkan statusnya rata- rata sebesar 9,36\%. (tabel 2).

Tabel 2 Kepemilikan PDAM di Kalimantan Selatan Tahun 2014

\begin{tabular}{clcccc}
\hline No & \multicolumn{1}{c}{ Nama PDAM } & $\begin{array}{c}\text { Kabupaten/ } \\
\text { Kota }\end{array}$ & $\begin{array}{c}\text { Pemprov } \\
\mathbf{( \% )}\end{array}$ & $\begin{array}{c}\text { Pemkab } \\
\text { Pemko } \\
\mathbf{( \% )}\end{array}$ & $\begin{array}{c}\text { Modal } \\
\text { Lainnya } \\
\mathbf{( \% )}\end{array}$ \\
\hline 1. & PDAM Kabupaten Barito Kuala & Batola & 13,32 & 83,65 & 3,03 \\
\hline 2. & PDAM Intan Banjar & Banjarbaru & 16,99 & 47,02 & 19,76 \\
\hline 3. & PDAM Kabupaten Balangan & Balangan & - & 16,23 & - \\
\hline 4. & PDAM Kabupaten Tanah Laut & Tala & 6,16 & 86,18 & 7,66 \\
\hline 5. & PDAM Kabupaten Hulu Sungai Tengah & HST & 3,88 & 94,80 & 1,32 \\
\hline 6. & PDAM Kabupaten Hulu Sungai Utara & HSU & 4,70 & 82,39 & 12,91 \\
\hline 7. & PDAM Kabupaten Tapin & Tapin & 13,75 & 65,05 & 21,20 \\
\hline 8. & PDAM Kabupaten Bandarmasih & Banjarmasin & 6,59 & 67,03 & 26,38 \\
\hline 9. & PDAM Kabupaten Hulu Sungai Selatan & HSS & 13,66 & 82,01 & 4,33 \\
\hline 10. & PDAM Kabupaten Tanah Bumbu & Tanah Bumbu & 22,69 & 76,84 & 0,40 \\
\hline 11. & PDAM Kabupaten Kotabaru & Kotabaru & 1,71 & 98,29 & 0,00 \\
\hline 12 & PDAM Kabupaten Tabalong & Tabalong & 15,49 & 56,29 & 28,22 \\
\hline & Rata-Rata & & $\mathbf{1 0 , 4 7}$ & $\mathbf{8 0 , 1 7}$ & $\mathbf{9 , 3 6}$ \\
\hline
\end{tabular}

Sumber : Laporan- laporan PDAM di Kalimantan Selatan 2014 dan 2015

\section{B. Potensi PDAM Dalam Menyumbang APBD Provinsi}

Penetapan penggunaan laba menurut Peraturan Daerah di Kabupaten/ Kota Di Kalimantan Selatan (seperti Perda Pemkab Batola No. 9/2013 dan Perda Pemkab Banjar No. 10/2011 serta Perda- Perda lainnya) ratarata bunyinya bahwa pembagian laba adalah Laba bersih setelah dikurangi pajak sebesar $55,00 \%$ dikalikan share Penyertaan Modal. Penyertaan Modal Pemerintah Provinsi terdapat pada 11 (sebelas) PDAM yang ada di Kalimantan Selatan (rata- rata 10,47\%), hanya PDAM Kabupaten Tabalong yang belum ada penyertaan modal Pemerintah Provinsi.

Di Kalimantan Selatan jumlah PDAM sebanyak 12 buah yang baru menghasilkan laba pada tahun 2014 sebanyak 3 buah, yaitu PDAM Intan Banjar sebesar Rp4.902.769.000,00, PDAM Bandarmasih sebesar Rp 12.224.110.000,00 dan PDAM Kabupaten Hulu Sungai Selatan sebesar Rp 639.566.000,00 (tabel 3). Tetapi untuk PDAM Kabupaten Hulu Sungai Selatan masih menanggung kerugian akumulatif pada tahun sebelumnya (Rp 3.560.615.000,00) sehingga sebenarnya jika dikurangkan dengan kerugian akumulatifnya maka masih rugi sebesar $\mathrm{Rp}$ 2.921.049.000,00. Sehingga yang dapat menyumbang PAD baru ada 2(dua) PDAM yaitu PDAM Intan Banjar dan PDAM Bandarmasih. Maka pembagiannya adalah sebesar 55,00\% dari laba setelah dikurangi pajak maka akan didapat seperti terlihat pada tabel 4.54. Hasil pembagian laba yang didapat Pemerintah Provinsi sebesar Rp1.376.536.000,00, tetapi jika dikurangi dengan kerugian maka masih besar kerugiaannya. Kerugian PDAM jika dilihat dari Perda-Perda yang mengaturnya belum dibagi pada peserta penyertaan modal.

Sebenarnya semua PDAM (12 Buah) punya potensi untuk menyumbang PAD Kabupaten/ Kota dan Provinsi Kalimantan Selatan, dengan catatan PDAM tersebut dikelola dan diawasi dengan baik, serta sangat perlu meninjau tarif agar harga jual air dapat menutup biaya produksinya secara penuh. 
Tabel 3 Pembagian Laba PDAM Di Kalimantan Selatan Tahun 2014

\begin{tabular}{|c|c|c|c|c|c|c|}
\hline No & Nama PDAM & $\begin{array}{l}\text { Kabupaten/ } \\
\text { Kota }\end{array}$ & $\begin{array}{c}\text { Laba } \\
\text { (rugi) } \\
\text { (RP 1000) }\end{array}$ & $\begin{array}{c}\text { Pemprov } \\
\text { (RP } \\
\text { 1000) }\end{array}$ & $\begin{array}{c}\text { Pemkab/ } \\
\text { Pemko } \\
\text { (Rp1000) }\end{array}$ & Lainnya \\
\hline 1. & PDAM Kabupaten Barito Kuala & Batola & $(19.743 .96)$ & - & - & - \\
\hline 2. & PDAM Intan Banjar & Banjarbaru & 4.902 .769 & 458.139 & 1.267 .905 & 532.833 \\
\hline 3. & PDAM Kabupaten Balangan & Balangan & - & - & 438.185 & - \\
\hline 4. & PDAM Kabupaten Tanah Laut & Tala & $(11.984 .14)$ & - & - & - \\
\hline 5. & $\begin{array}{l}\text { PDAM Kabupaten Hulu Sungai } \\
\text { Tengah }\end{array}$ & HST & $(1.316 .210)$ & - & - & - \\
\hline 6. & $\begin{array}{l}\text { PDAM Kabupaten Hulu Sungai } \\
\text { Utara }\end{array}$ & $\mathrm{HSU}$ & $(1.047 .670)$ & - & - & - \\
\hline 7. & PDAM Kabupaten Tapin & Tapin & $(2.481 .951)$ & - & - & - \\
\hline 8. & PDAM Kabupaten Bandarmasih & Banjarmasin & $(6.522 .628)$ & - & - & - \\
\hline 9. & $\begin{array}{l}\text { PDAM Kabupaten Hulu Sungai } \\
\text { Selatan }\end{array}$ & HSS & 12.224 .110 & 918.397 & 5.513 .746 & 291.117 \\
\hline 10. & $\begin{array}{l}\text { PDAM Kabupaten Tanah } \\
\text { Bumbu }\end{array}$ & $\begin{array}{l}\text { Tanah } \\
\text { Bumbu }\end{array}$ & 639.566 & - & - & - \\
\hline 11. & PDAM Kabupaten Kotabaru & Kotabaru & $(19.045 .65)$ & - & - & - \\
\hline 12 & PDAM Kabupaten Tabalong & Tabalong & $(3.263 .278)$ & - & - & - \\
\hline & Jumlah & & & 1.376 .536 & & \\
\hline
\end{tabular}

Sumber: Laporan - laporan PDAM di Kalimantan Selatan, 2014

\section{Potensi PDAM Dalam Menyumbang PAD Kabupaten / Kota di Kalimantan Selatan}

Dilihat dari 13 kabupaten/kota yang mempunyai PDAM, yang mendapatkan bagian dari laba adalah baru 3 (tiga) daerah yaitu:

1. Kabupaten Banjar.

Kabupaten Banjar memiliki PDAM Intan Banjar bersama dengan Kota Banjarbaru. Hasil perhitungan pembagian laba untuk tahun 2014 (setelah dikurangi pajak Rp 4.902.697.000,00, kemudian dibagi sesuai dengan Perda Pemkab Banjar No. 10/2011 maka bagian laba yang dapat masuk ke kas Pemkab Banjar sebagai PAD adalah sebesar Rp 1.267.905.000,00. (tabel 4.54). Potensi PAD untuk tahun- tahun kedepan akan semakin meningkat mengingat PDAM Intan Banjar memproduksi air kemasan yang punya nilai ekonomis lebih tinggi dan menyumbang potensi laba yang besar.

2. Kota Banjarbaru.

Kota Banjarbaru memiliki PDAM Intan Banjar bersama dengan Kabupaten Banjar dengan share penyertaan modal sebesar Rp 16,25\%. Hasil perhitungan pembagian laba untuk tahun 2014 (setelah dikurangi pajak Rp 4.902.697.000,00, kemudian dibagi sesuai dengan Perda Pemkab Banjar No. 10/2011 maka bagian laba yang dapat masuk ke kas Pemko Banjarbaru sebagai PAD adalah sebesar Rp 438.185.000,00. (tabel 4.54). Potensi PAD untuk tahuntahun kedepan akan semakin meningkat mengingat PDAM Intan Banjar memproduksi air kemasan yang punya nilai ekonomis lebih tinggi dan menyumbang potensi laba yang besar.

3. Kota Banjarmasin

Kota Banjarmasin memiliki PDAM Bandarmasih Hasil perhitungan pembagian laba untuk tahun 2014 (setelah dikurangi pajak Rp12.224.110.000,00, kemudian dibagi sesuai dengan Perda Pemko Banjarmasin maka bagian laba yang dapat masuk ke kas Pemko Banjarmasin sebagai PAD adalah sebesar Rp 5.513.746.000,00. (tabel 4.54). Potensi PAD untuk tahuntahun kedepan akan semakin meningkat mengingat PDAM Bandarmasih sudah menjual air diatas biaya produksinya dan sudah $\quad 100,00 \%$ penduduk Kota Banjarmasin sudah menjadi pelanggan.

4. Kabupaten Barito Kuala.

Kabupaten Barito Kuala mempunyai PDAM dengan nama PDAM Kabupaten Barito Kuala dan sampai akhir 2014 masih mengalami belum sehat dan terus mengalami kerugiaan sehingga belum dapat menyumbang PAD. Kerugiaannya sangat besar yaitu sampai tahun 2014 mencapai Rp Rp 19.743.967.000,00. 
5. Kabupaten Balangan.

Kabupaten Balangan mempunyai PDAM dengan nama PDAM Kabupaten Balangan dan sampai akhir 2014 masih mengalami belum sehat dan terus mengalami kerugiaan sehingga belum dapat menyumbang PAD. Kerugiaannya sangat besar yaitu sampai tahun 2014 mencapai Rp 11.984.144.000,00.

6. Kabupaten Tanah Laut

Kabupaten Tanah Laut mempunyai PDAM dengan nama PDAM Kabupaten Tanah Laut dan sampai akhir 2014 masih mengalami belum sehat dan terus mengalami kerugiaan sehingga belum dapat menyumbang PAD. Kerugiaannya cukup besar yaitu sampai tahun 2014 mencapai Rp 1.316.210.000,00.

7. Kabupaten Hulu Sungai Tengah Kabupaten Hulu Sungai Tengah mempunyai PDAM dengan nama PDAM Kabupaten Hulu Sungai Tengah dan sampai akhir 2014 masih mengalami belum sehat dan terus mengalami kerugiaan sehingga belum dapat menyumbang PAD. Kerugiaannya cukup besar yaitu sampai tahun 2014 mencapai Rp 1.047.670.000,00.

8. Kabupaten Hulu Sungai Utara

Kabupaten Hulu Sungai Utara mempunyai PDAM dengan nama PDAM Kabupaten Hulu Sungai Utara dan sampai akhir 2014 masih mengalami belum sehat dan terus mengalami kerugiaan sehingga belum dapat menyumbang PAD. Kerugiaannya cukup besar yaitu sampai tahun 2014 mencapai Rp 2.481.951.000,00.

9. Kabupaten Hulu Sungai Selatan

Kabupaten Hulu Sungai Selatan (HSS) mempunyai PDAM dengan nama PDAM Kabupaten Hulu Sungai Selatan dan sampai akhir 2014 sudah sehat (mendapat laba Rp 639.565.577.000,00) tetapi belum dapat menyumbang PAD, hal ini disebabkan adanya akumulasi kerugiaannya cukup besar pada tahun sebelumnya (Rp 3.560.615.000,00). Sehingga jika dikurangkan dengan akumulasi kerugian tahun sebelumnya maka masih mengalami kerugian sebesar Rp 2.921.049.000,00.

10. Kabupaten Kotabaru Kabupaten Kotabaru mempunyai PDAM dengan nama PDAM Kabupaten Kotabaru dan sampai akhir 2014 masih mengalami belum sehat dan terus mengalami kerugiaan sehingga belum dapat menyumbang PAD. Kerugiaannya cukup besar yaitu sampai tahun 2014 mencapai Rp 3.263.278.000,00.
11. Kabupaten Tapin

Kabupaten Tapin mempunyai PDAM dengan nama PDAM Kabupaten Tapin dan sampai akhir 2014 masih mengalami belum sehat dan terus mengalami kerugiaan sehingga belum dapat menyumbang PAD. Kerugiaannya cukup besar yaitu sampai tahun 2014 mencapai Rp 6.522.628.000,00.

12. Kabupaten Tanah Bumbu

Kabupaten Tanah Bumbu mempunyai PDAM dengan nama PDAM Bersujud Kabupaten Tanah Bumbu dan sampai akhir 2014 masih mengalami belum sehat dan terus mengalami kerugiaan sehingga belum dapat menyumbang PAD. Kerugiaannya sangat besar yaitu sampai tahun 2014 mencapai Rp 19.045.657.000,00.

13. Kabupaten Tabalong

Kabupaten Tabalong mempunyai PDAM dengan nama PDAM Kabupaten Tabalong dan sampai akhir 2014 masih mengalami belum sehat dan terus mengalami kerugiaan sehingga belum dapat menyumbang PAD. Kerugiaannya cukup besar yaitu sampai tahun 2014 mencapai Rp 1.151.216.000,00.

\section{Faktor- Faktor Yang Mempengaruhi Kinerja PDAM}

Dari hasil penelitian ditemukan bahwa yang mempengaruhi kinerja PDAM di Kalimantan Selatan dapat dibagi 2 (dua), yaitu pertama yang berhubungan dengan internal meliputi permodalan, manajemen (terutama keadaan karyawan), dan yang kedua yang berhubungan dengan eksternal yang meliputi ekonomi lokal.

1. Faktor Permodalan.

Masalah permodalan ini sangat mendesak untuk dibenahi. Kecilnya modal yang dimiliki oleh PDAM sangat mempengaruhi kinerja PDAM. Masih kurangnya modal mengakibatkan banyak PDAM di Kalimantan Selatan yang tidak dapat melayani masyarakat sesuai dengan sasaran RPJMN. Sehingga cakupan pelayanan dibeberapa kabupaten masih jauh dari harapan, bahkan PDAM Kabupaten Tanah laut baru dapat melayani masyarakat sebanyak $9,86 \%$ dari jumlah penduduk (2014), dilain pihak sasaran RPJMN pada tahun 2014 harus mencapai minimum sebanyak $67,00 \%$.

2. Faktor Karyawan

Karyawan dalam pengelolaan PDAM juga sangat penting. Hasil penelitian sebagian besar karyawan yang ada pada PDAM adalah lulusan SLTA atau yang lulusan S1 
yang belum punya kemampuan untuk mengelola PDAM. Kedepan jika modal ditambah oleh pemilik PDAM (Pemerintah Provinsi dan Pemerintah Kabupaten) dalam merekrut karyawannya sangat perlu diperhatikan kemampuannya.

3. Faktor Keadaan Ekonomi

Keadaan ekonomi apalagi nasional dan regional sangat berpengaruh terhadap kinerja PDAM di Kalimantan Selatan. Dengan kondisi ekonomi yang kurang baik maka banyak pelanggan PDAM yang menunggak pembayaran, penunggak ini sangat mempengaruhi kinerja PDAM.

\section{Penutup}

\section{A. Kesimpulan}

Berdasarkan pembahasan yang telah diuraikan diatas maka dapat disimpulkan sebagai berikut:

1. PDAM yang sehat pada tahun 2013 dan 2014, yaitu PDAM Intan Banjar, PDAM Bandarmasih dan PDAM Kabupaten Hulu Sungai Selatan. Tetapi PDAM Kabupaten Hulu Sungai Selatan sebenarnya masih menanggung kerugian yang besar pada tahun- tahun sebelumnya sehingga jika keuntungan yang didapat pada tahun 2013 dan 2014 dikurangi dengan kerugian yang terjadi pada tahun sebelumnya maka PDAM Kabupaten Hulu Sungai Selatan masih mengalami kerugian. Jika PDAM sehat maka akan dapat menghasilkan laba sehingga dapat menyumbang Pendapatan Asli Daerah (PAD), atau minimal tidak membebani APBD.

2. Penyebab utama ruginya PDAM adalah disebabkan tarif yang masih rendah (harga jual belum menutupi biaya produksi secara penuh). Memang jadi delematis bagi Pemerintah Daerah untuk menaikkan tarif air. Jika dinaikkan tarif maka konsumen (masyarakat) berpenghasilan rendah akan tidak mampu membayarnya, padahal ada tugas Pemerintah Daerah untuk mensejahterakan rakyatnya dengan mengkonsumsi air bersih. Memang berbeda Perusahaan Negara/ Daerah dengan perusahaan swasta, jika perusahaan swasta yang tujuannya mencari keuntungan maksimum,tetapi perusahaan daerah tujuannya lebih banyak diartikan untuk mencapai kesejahteraan umum (summum bonum).
3. PDAM yang mempunyai potensi besar untuk menyumbang PAD Provinsi Kalimantan Selatan dan kabupaten/kota adalah sebanyak 12 buah, potensi ini akan terjadi jika dilakukan perbaikan modal, manajemen dan pengawasan.

\section{B. Rekomendasi}

1. Hendaknya Pemerintah Provinsi dan Pemerintah Kabupaten sebagai pemilik PDAM meningkatkan pengawasan dan pembinaannya. Dengan makin baiknya pengawasan maka kinerja PDAM akan makin baik dan tingkat kesehatan makin baik sehingga labanya makin meningkat.

2. Hendaknya Pemerintah Provinsi dan Pemerintah Kabupaten meningkatkan modal setor agar dapat memenuhi ketentuan ketersediaan air bersih menjadi mutlak untuk dilakukan karena hal ini juga terkait dengan sasaran nasional/target nasional bahwa tingkat cakupan pelayanan yang harus dicapai adalah sebesar $80,00 \%$ penduduk di wilayah perkotaan dan $60,00 \%$ di wilayah perdesaan pada tahun 2015 (Millenium Development Goals), dari 12 PDAM baru 2(dua) buah PDAM yang mencapainya (PDAM Bandarmasih dan PDAM Balangan).

3. Hendaknya kualitas karyawan PDAM ditingkatkan dan jika PDAM mendapatkan tambahan setoran modal dari Pemerintah, maka jika menambah karyawan untuk berekspansi perlu diperhatikan tingkat pendidikannya yang sesuai dengan keperluan perkembangan PDA.

\section{Daftar Pustaka}

Carter, William K. 2012. Akuntansi Biaya, Cetakan Pertama Edisi Keempat Belas, Salemba Empat, Jakarta.

Daljono. 2011. Akuntansi Biaya, Edisi Ketiga, Penerbit Universitas Diponegoro, Semarang.

Draft, Richad L. 2008. Manajemen.Dasar-dasar Akuntansi, Edisi Keenama. Penerbit Sekolah Tinggi Ilmu Ekonomi YKPN. Yogyakarta.

Firdaus Ahmad Dunia dan Wasilah Abdullah. 2012. Akuntansi Biaya, Edisi Kedua, Salemba Empat, Jakarta.

Haryono Jusuf. 2005. Dasar-dasar Akuntansi, Jilid satu Edisi 5, Aditya Media. Yogyakarta.

IAI. 2012. Standar Akuntansi Keuanga, Jakarta. Mulyadi. 2012, Akuntansi Biaya, Edisi Kelima Cetakan Kesebelas, Universitas Gadjah Mada. Yogyakarta. 
Mursyidi, Drs. SE.M.Si., 2010. Akuntansi Biaya, Refika Utama. Bandung.

Riza Kautsar, Salman. 2013. Akuntansi Biaya, Pendekatan product costing. Akademia Permata. Jakarta.

Supriyono. 2011. Akuntansi Biaya, BPFE. Yogyakarta.

Suwardjono. 2010. Akuntansi Pengantar, Cetakan Pertama Edisi Ketiga, BPFE. Yogyakarta.
Soporno, Bambang, dan Nur Indriantoro. Metodologi Penelitian Bisnis, Untuk Akuntansi dan Manajemen. Edisi Pertama. BPFE.Yogyakarta.

Wijatno, serian. 2009. Pengantar Entrepreneurship, Grasindo. Jakarta. 